\title{
The more things change ... the more things change: developmental plasticity of tumor- initiating mammary epithelial cells
}

\author{
Michael T Lewis* \\ See related research by Meyer et al., http://breast-cancer-research.com/content/11/6/R82
}

\begin{abstract}
In our haste to find and eliminate breast cancer stem cells, it appears as though we may have missed something. Contrary to current thought, a recent paper by Meyer and colleagues demonstrates developmental plasticity of breast cancer cells with respect to the CD24 cell surface marker, such that

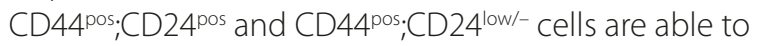
give rise to one another in an activin/nodal-dependent manner, and that cells derived from single cells of either phenotype are capable of forming tumors as xenografts. If confirmed clinically, these data imply that simply targeting the CD44 ${ }^{\text {pos }} ; C^{\prime}$ D2 $4^{\text {low/- }}$ breast cancer stem cell for breast cancer treatment may be destined to fail unless this plasticity is taken into account and prevented.
\end{abstract}

Change - the one thing you can count on ...

A recent paper by Meyer and colleagues reminds us of this statement, and suggests we may have forgotten something in our rush to exploit the first set of breast cancer stem cell markers identified [1]. Namely, a full analysis of the developmental and tumor-initiating potential of the CD44 ${ }^{\text {pos; }}$ CD24 $4^{\text {pos }}$ breast cancer cell.

In 2003, two cell surface markers - CD44 $4^{\text {high }}$ and CD24 $4^{\text {low/- }}$ - were associated with breast cancer stem cells [2]. In xenograft transplantation studies, this cell population regenerated tumors at high frequency whereas other cell populations were depleted for this function.

*Correspondence: mtlewis@bcm.edu

Lester and Sue Smith Breast Center, Department of Molecular and Cellular Biology, and Department of Radiology, One Baylor Plaza, BCM600, Room N1210, Houston, TX77030, USA
Subsequent work in breast cancer cell lines showed that CD $44^{\text {high }} ; C D 24^{\text {low/- }}$ cells were present in culture, and were also tumorigenic upon transplantation, with CD24 positivity being associated with decreased invasiveness (for example $[3,4])$. Naturally, this work set off a flurry of activity to characterize the $\mathrm{CD} 44^{\text {high }} ; \mathrm{CD} 24^{\text {low/- }}$ population molecularly relative to other populations present in tumors [5-8], and to evaluate their response to treatment (for example $[9,10]$ ).

In the wake of this flurry of activity, it appears we may have forgotten something - to determine the full developmental and tumor-initiating potential of the CD44 ${ }^{\text {pos; }}$ CD24 ${ }^{\text {pos }}$ cell. The recent paper by Meyer and colleagues confirms that $\mathrm{CD} 44^{\text {pos }} ; \mathrm{CD} 24^{\text {low/- }}$ cells in a number of cell lines can give rise to CD44 $4^{\text {pos; }}$ CD24 $4^{\text {pos }}$ cells, and can yield total populations characteristic of the parental line [1]. This finding is not surprising, and in fact is as expected for a cancer stem cell. Using flow cytometry and single cell culture, however, these authors went on to show that the converse can also occur CD44 ${ }^{\text {pos; }}$ CD24pos cells can give rise to their CD $44^{\text {pos; }}$ CD24 $4^{\text {low/- }}$ counterparts, and are subsequently also capable of initiating tumors as xenografts with high efficiency. Further, their paper shows that the developmental potential for either CD44 ${ }^{\text {pos }}$ cell population to regenerate the other was dependent on activin/nodal signaling.

While the analysis was limited to established cell lines, what these data imply is that the status of CD24 is dynamically regulated in a developmental context, and suggests that the CD24 status may ultimately be immaterial as to whether or not the CD44 pos population is capable of initiating tumors. In addition, these data also imply that current efforts by many groups to develop agents that specifically target the CD $44^{\text {high }} ; \mathrm{CD} 24^{\text {low/- }}$ population may be destined to fail unless activin/nodal signaling is also prevented.

Aside from the potential implications on translational research, if confirmed clinically, these results beg the 
question of why we tend to consider mammary tumorinitiating cells as static entities given the fact that the plasticity of normal mammary epithelial cells is, in some circles, the stuff of legends [11].

In the normal gland, plasticity comes in a couple of different forms. First, cellular plasticity - the character of a given cell can change dramatically over the course of gland development (for example, virgin ducts versus pregnancy, or lactation versus involution), and in response to treatment with a bioactive agent (for example, hormones, growth factors). Similarly, there is developmental plasticity - the observation that subsets of mammary epithelial cells retain the ability to give rise to multiple cell types at defined phases of development, although they do not express this ability until needed.

As an example of cellular plasticity, cells already present within the duct of a virgin mouse (and probably of human) in early pregnancy are induced to proliferate and ultimately give rise to alveolar structures capable of producing copious amounts of milk. At least some of these cells can be parity identified after the fact using elegant genetic tagging methods sensitive to at least some degree of alveolar differentiation. Transplantation of these tagged populations suggests that a subset of differentiated alveolar epithelial cells survive the involution process after weaning and retain a high degree of regenerative and multilineage differentiation capacity upon transplantation $[12,13]$.

With respect to developmental plasticity, we know that regenerative stem cells are present throughout the mature mammary gland in the virgin animal. Small fragments of duct derived from any portion of the gland are capable of regenerating a functional mammary gland when transplanted into a mammary fat pad lacking its endogenous epithelium $[14,15]$. If a fragment of duct is transplanted into an intact mammary fat pad already containing epithelium, however, it does not regenerate. Further, actively growing terminal end buds in the mammary gland, which by definition contain regenerative stem cells, do not run into each other and, in fact, are regularly spaced from one another throughout the mammary gland [14].

The inference is that regenerative stem cells resident in the mature duct are not generally actively engaged in stem cell behaviors, and are strongly growth-inhibited by the presence of neighboring normal mammary epithelium. The behavior of regenerative stem cells is thus entirely dependent on the environment in which it finds itself. Further, there is high probability that gene expression in an actively regenerating stem cell is probably quite different from gene expression in a quiescent stem cell.

If normal mammary epithelial cells are plastic, why should we not expect malignant epithelium to share this characteristic?
We are clearly in desperate need of new, rigorously validated, markers of normal and malignant stem cells. Perhaps most importantly, however, we need to ensure that newly emerging therapeutics intended to target tumor-initiating cancer stem cells are evaluated carefully for their ability to eliminate all sources of such cells completely, lest they find a way to express the developmental plasticity with which they appear to be endowed.

\section{Change - count on it.}

\section{Competing interests}

The author declares that he has no competing interests.

Published: 19 January 2010

\section{References}

1. Meyer MJ, Fleming JM, Ali MA, Pesesky M, Ginsburg E, Vonderhaar BK: Dynamic regulation of $C D 24$ and the invasive, $C D 44^{\text {pos }} C D 24^{\text {neg }}$ phenotype in breast cancer cell lines. Breast Cancer Res 2009, 11:R82.

2. Al-Hajj M, Wicha MS, Benito-Hernandez A, Morrison SJ, Clarke MF: Prospective identification of tumorigenic breast cancer cells. Proc Natl Acad Sci U S A 2003, 100:3983-3988.

3. Fillmore CM, Kuperwasser C: Human breast cancer cell lines contain stemlike cells that self-renew, give rise to phenotypically diverse progeny and survive chemotherapy. Breast Cancer Res 2008, 10:R25.

4. Sheridan C, Kishimoto H, Fuchs RK, Mehrotra S, Bhat-Nakshatri P, Turner CH, Goulet R, Jr, Badve S, Nakshatri H: CD44+/CD24- breast cancer cells exhibit enhanced invasive properties: an early step necessary for metastasis. Breast Cancer Res 2006, 8:R59.

5. Shipitsin M, Campbell LL, Argani P, Weremowicz S, Bloushtain-Qimron N, Yao J, Nikolskaya T, Serebryiskaya T, Beroukhim R, Hu M, Halushka MK, Sukumar S, Parker LM, Anderson KS, Harris LN, Garber JE, Richardson AL, Schnitt SJ, Nikolsky Y, Gelman RS, Polyak K: Molecular definition of breast tumor heterogeneity. Cancer Cell 2007, 11:259-273.

6. Creighton CJ, Li X, Landis M, Dixon JM, Neumeister VM, Sjolund A, Rimm DL, Wong H, Rodriguez A, Herschkowitz Jl, Fan C, Zhang X, He X, Pavlick A, Gutierrez MC, Renshaw L, Larionov AA, Faratian D, Hilsenbeck SG, Perou CM, Lewis MT, Rosen JM, Chang JC: Residual breast cancers after conventional therapy display mesenchymal as well as tumor-initiating features. Proc Natl Acad Sci U S A 2009, 106:13820-13825.

7. Bloushtain-Qimron N, Yao J, Snyder EL, Shipitsin M, Campbell LL, Mani SA, Hu M, Chen H, Ustyansky V, Antosiewicz JE, Argani P, Halushka MK, Thomson JA, Pharoah P, Porgador A, Sukumar S, Parsons R, Richardson AL, Stampfer MR, Gelman RS, Nikolskaya T, Nikolsky Y, Polyak K: Cell type-specific DNA methylation patterns in the human breast. Proc Natl Acad Sci U S A 2008, 105:14076-14081.

8. Liu R, Wang X, Chen GY, Dalerba P, Gurney A, Hoey T, Sherlock G, Lewicki J, Shedden K, Clarke MF: The prognostic role of a gene signature from tumorigenic breast-cancer cells. N Eng/ J Med 2007, 356:217-226.

9. Li X, Lewis MT, Huang J, Gutierrez C, Osborne CK, Wu MF, Hilsenbeck SG, Pavlick A, Zhang X, Chamness GC, Wong H, Rosen J, Chang JC: Intrinsic resistance of tumorigenic breast cancer cells to chemotherapy. J Natl Cancer Inst 2008, 100:672-679.

10. Phillips TM, McBride WH, Pajonk F: The response of CD24-/low $/ C D 44^{+}$breast cancer-initiating cells to radiation. J Nat/ Cancer Inst 2006, 98:1777-1785.

11. Lochter A: Plasticity of mammary epithelia during normal development and neoplastic progression. Biochem Cell Biol 1998, 76:997-1008.

12. Boulanger $\mathrm{CA}$, Wagner KU, Smith GH: Parity-induced mouse mammary epithelial cells are pluripotent, self-renewing and sensitive to TGF- $\beta 1$ expression. Oncogene 2005, 24:552-560.

13. Matulka LA, Triplett AA, Wagner KU: Parity-induced mammary epithelial cells are multipotent and express cell surface markers associated with stem cells. Dev Biol 2007, 303:29-44.

14. Faulkin $L$, Jr, Deome KB: Regulation of growth and spacing of gland 
elements in the mammary fat pad of the $\mathrm{C} 3 \mathrm{H}$ mouse. J Nat/ Cancer Inst 1960, 24:953-969.

15. DeOme KB, Faulkin LJJ, Bern H: Development of mammary tumors from hyperplastic alveolar nodules transplanted into gland-free mammary fat pads of female C3H mice. Cancer Res 1958, 19:515-520. doi:10.1186/bcr2459

Cite this article as: Lewis MT: The more things change ... the more things change: developmental plasticity of tumor-initiating mammary epithelial cells. Breast Cancer Research 2010, 12:101. 